\title{
ヘテロ組織制御による高機能材料創製 \\ Special Interest Session: Creation of High Performance Metallic Materials by Hetero-Structure Design
}

\author{
飴山 惠 \\ Kei AMEYAMA \\ 立命館大学 \\ Ritsumeikan University
}

金属材料の強度と延性は両立せず，トレードオフの関係で あることはよく知られています。その大前提は材料の組織が 「均一」であることですが，例えば，局所的な組織が周期的 に変化するようなへテロ構造では, 微視的な塑性変形とマク 口な構造由来の変形が重畳し, 新しい変形様式が生まれ, 高 強度と高延性・高靱性が両立する可能性が考えられます。

本企画セッションでは, 構造材料の宿命とされてきた強度 と延性の二律背反問題をへテロ組織制御で解決することを目 標として，多方面からの議論を行うことを目的としました.

本企画セッションでは 2 件の特別講演と 6 件の一般講演が ありました。

1 つ目の特別講演「鉄原子固溶 $\alpha / \beta 2$ 相チタン焼結合金の 強化機構（阪大：近藤勝義先生）では，粉末治金法を用いた 焼結材の局所的な不均一（ヘテロ）組織形成について，チ夕 ン合金における希少金属に代わる廉価な元素を活用し, 高強 度と高延性の両立を可能とする新たな材料設計指針について 講演されました．鉄固溶量が増加することで微細な $\alpha-T i$ 結 晶粒の形成が促進されて力学特性向上に結びつくことが報告 されました．2つ目の特別講演「調和組織を有するチタン系 材料の疲労き裂発生および伝ぱメカニズム」（静岡大 : 菊池 将一先生）は金属材料全般で高強度と高延性が両立すること が明らかとなった調和組織材料の, 特にチタン合金における 特異な疲労特性について講演されました。チタン系調和組織
材料では優れた力学特性が知られていますが, 疲労特性につ いても良好な性質が現れ，またどのように疲労き裂の発生と 進展が生じるかについても報告されました.

一般講演では, $\mathrm{Al}$ 系, 鉄系, 銅系ならびにチタン系のへ テロ構造材料について, 特に調和組織材料の特異性に着目し た研究成果が報告されました，Al系ではAl-CNT の複合へテ ロ構造材の創製プロセスが報告され，鉄系では低炭素鋼の フェライト・パーライト組織を有効活用した調和組織制御に ついて，また，銅ならびに純チタンの調和組織材料の加工熱 処理での選択的な再結晶挙動について報告がありました．特 に, 選択的再結晶は, 従来の均一組織材料では起こらないよ うな, 任意の場所（微細粒ネットワーク部）での優先的な再 結晶を見いだしたという点で関心を集めました。調和組織材 料における応力集中ならびに応力分散を活用した組織制御研 究が活発に展開されていることがうかがわれました.

以上のように，高強度と高延性を両立させた構造用金属材 料の創製のためには，ヘテロ組織制御が不可欠な手法である ことが指摘されました，様々な金属材料のへテロ組織制御に ついて, 今後さらに活発に研究が進められて行くことが期待 されます。この紙面をお借りして，ご講演いただいた方々， ならびに活発な議論に参加いただいた皆様に，本企画セッ ションの企画者として深くお礼申し上げます。 